\title{
Evaluation of Heavy Metals in Drinking Water Resources in the Department of Nyan, Province of Logone Oriental in Chad
}

\author{
Ngaram Nambatingar ${ }^{1, ~ *}$, Maoudombaye Theophile ${ }^{2}$, Tarkodjiel Mianpeureum ${ }^{1}$ \\ ${ }^{1}$ Department of Chemistry, Faculty of Exact and Applied Sciences, University of N'Djamena, N'Djamena, Chad \\ ${ }^{2}$ Department of Chemistry, Biology, Geology, Faculty of Science and Technology, University of Doba, Doba, Chad
}

Email address:

ngaramn@yahoo.fr (N. Nambatingar)

${ }^{*}$ Corresponding author

\section{To cite this article:}

Ngaram Nambatingar, Maoudombaye Theophile, Tarkodjiel Mianpeureum. Evaluation of Heavy Metals in Drinking Water Resources in the Department of Nyan, Province of Logone Oriental in Chad. American Journal of Applied Chemistry. Vol. 9, No. 1, 2021 , pp. 13-20. doi: 10.11648/j.ajac.20210901.13

Received: December 28, 2020; Accepted: January 15, 2021; Published: January 22, 2021

\begin{abstract}
The present research work was carried out in the Department of Nyan, Province of Logone Oriental. It allowed the quantification of heavy metal contents in well, borehole and river water intended for human consumption. Samples from these water sources were collected and submitted for laboratory analysis. Structural quality indicators such as $\mathrm{pH}$, temperature, electrical conductivity, turbidity, dissolved oxygen and sulphate ions were measured first. The sample was acidified and the measurement is then performed on the metals, i.e. barium, calcium, iron, magnesium, manganese, copper, chromium, aluminium, lead, strontium, tin, zirconium and titanium. The results of the quality indicators showed that well and borehole waters have an acidic $\mathrm{pH}$; their average measured values are $5.34 \pm 0.24$ and $5.48 \pm 0.15$ respectively. Well water and that of rivers have high turbidity values averaging $43.40 \pm 1.21$ NTU and $47.56 \pm 1.5$ NTU respectively. With respect to metals, some have values above the WHO drinking water standards. These include iron, which has high values in well water $(7.890 \pm 0.016$ $\mathrm{mg} / \mathrm{L})$ and river water $(0.866 \pm 0.003 \mathrm{mg} / \mathrm{L})$, manganese in well water $(0.093 \pm 0.001 \mathrm{mg} / \mathrm{L})$, aluminum in well water $(5.614 \pm 0.009 \mathrm{mg} / \mathrm{L})$ and river water $(1.211 \pm 0.008 \mathrm{mg} / \mathrm{L})$. Based on these results, consumption of these water sources would expose communities to mild or chronic health risks.
\end{abstract}

Keywords: Drinking Water, Heavy Metals, Nyan Department, Logone Oriental, Chad

\section{Introduction}

The term "heavy metals" refers to natural metallic elements, metals or in some cases metalloids, characterized by a high density greater than $5 \mathrm{~g} / \mathrm{cm}^{3}[1]$. They are natural constituents of all ecosystems and are found in the atmosphere, hydrosphere, lithosphere and biosphere [2]. Heavy metals have very different effects on the living environment. Some are necessary for organisms; they are called "essential", although at high concentrations they can be harmful to living organisms [3]. Heavy metals are ubiquitous in surface waters, however, their concentrations are generally very low, which explains their denomination as "trace metals" or "trace metal elements" (TMEs) [4]. Because they are not degradable in soil, heavy metals can persist in soil for long periods of time and constitute a potential hazard through bioaccumulation along the trophic chain $[5,6]$. Permanent exposure to small doses of heavy metals can trigger many reactions in humans [7]. Among the first are cardiovascular diseases [7]. Heavy metals can contribute to immunological pathologies such as multiple sclerosis or other defects of the immune system. They also tend to disrupt the reproductive and endocrine systems and have cytotoxic effects [8]. Neurotoxic effects occur directly when heavy metals cross the brain barrier, causing central nervous system damage such as Parkinson's and Alzheimer's disease and, in the fetus, disruption of brain development [8]. The objective of this work is to evaluate some heavy metals and quality indicators in water resources for drinking in the Department of Nyan, Doba oil zone in southern Chad. 


\section{Materials and Methods}

\subsection{Presentation of the Study Site}

The Province of Logone Oriental is one of the twentythree (22) Provinces of the Republic of Chad. Geographically, the Eastern Logone Province is located in southern Chad between the 8th and 9th parallels of northern latitude and the 16th and 17th parallels of eastern longitude. It has 1,027 villages, 42 cantons and 23 sub-prefectures in 6 departments [9].

The choice of the study area was guided by its proximity to oil wells and the problem of drinking water supply [10]. Indeed, in 2009, about 24 villages located in the oil fields were declared "impacted by the oil project (stress and tree decline, fish mortality...)" according to the classification of the socio-economic team of ESSO (the oil consortium that operates the Doba Basin) in its 2009 quarterly reports. Most of these villages are located in the Department of Nyan, whose chief town is Bébédjia, the second largest city in the Petroleum Province. This department is home to most of the oil installations: the extraction wells of Komé, Miandoum, Bolobo, Nyan, Maikiri, Moundouli and Timbré and the water injection wells that ESSO had to drill next to the extraction wells to reinject water to maintain the level of production [11].

The Department of Nyan is therefore the area where the environment is most adversely affected by the project. In addition to the wells drilled, the crude oil collection centers and other oil installations, the zone is crossed by countless tracks, some leading to the collection centers, others following the lines of the pipelines [11]. Alongside this gigantic system, one can see quarries that were opened for construction purposes and that have been rehabilitated but abandoned for the most part because they are unsuitable for agriculture [11].

\subsection{Methodology}

\subsubsection{Sample Collection}

Taking a water sample is a delicate operation to which the greatest care must be taken. It determines the analytical results and the interpretation that will be given [12]. The physico-chemical parameters were determined from samples taken from the tributaries of the Logone River, which are the Nyan and Loule, from traditional wells and human-powered boreholes. The geographical coordinates of the following water points considered as sampling stations were recorded thanks to a GARMIN etrex 10 GPS:

Station 1: $08^{\circ} 28,324^{\prime} ; 16^{\circ} 35,203^{\prime}$ : traditional well of the village Poutgueum;

Station 2: $08^{\circ} 43.132^{\prime} ; 16^{\circ} 43.728^{\prime}$ : traditional well of the village Deubeu;

Station 3: $08^{\circ} 28.299^{\prime} ; 1^{\circ} 35.438^{\prime}$ : Nyan river near the village Poutgueum;

Station 4: $08^{\circ} 30.363^{\prime} ; 1^{\circ} 36.709^{\prime}$ : Nyan river at the Mboh Nyan bridge;

Station 5: $08^{\circ} 30,977^{\prime} ; 16^{\circ} 37,752^{\prime}$ : river next to the Madana
Garden;

Station 6: $08^{\circ} 31.527^{\prime} ; 16^{\circ} 46.763^{\prime}$ : "Loulé" river;

Station 7: $08^{\circ} 41,312^{\prime} ; 16^{\circ} 44,705^{\prime}$ : river Nyan downstream of the Mboh Nyan bridge;

Station 8: $08^{\circ} 27.479^{\prime} ; 16^{\circ} 34.652^{\prime}$ : Nyan river upstream of the Mboh Nyan bridge;

Station 9: $08^{\circ} 30.414^{\prime} ; 1^{\circ} 37.883^{\prime}$ : drilling at Madana Nadpeur village;

Station 10: $08^{\circ} 32.607^{\prime} ; 1^{\circ} 50.295^{\prime}$ : drilling at Dokaïdilti village (Swissaid drilling).

With regard to surface water, the sampling points were chosen according to the accessibility and frequency of anthropogenic activity. Thus, samples were taken using a probe in areas where the water flow is not disturbed (natural obstacles, tree trunks, etc.) [13]. The samples were taken at a depth of $0.5 \mathrm{~m}$ below the water surface in plastic bottles that were cleaned and rinsed with distilled water.

For the wells, the choice of samples was a reasoned choice: wells without coping stones, untreated and not monitored by hygiene and sanitation services but normally consumed by the population. The well water was drawn from a bucket and a probe was used to take samples for analysis.

In order to ensure the representativeness of the samples, the borehole water was collected after purging the casing [14, $15]$ at least 5 minutes before sampling.

All sampling was carried out under good atmospheric conditions. Samples are stored and transported in coolers and deposited at the laboratory the following day to ensure their stability. Keeping the samples at a low temperature, 2 to $4^{\circ} \mathrm{C}$, is an effective condition to avoid changes in the composition of the samples that may be caused by the action of the microorganisms present and chemical reactions.

\subsubsection{Sample Analysis}

Given the organic load of the waters and their rapid biodegradability, the physicochemical parameters likely to be altered were measured in situ. These parameters, indicators of quality, namely $\mathrm{pH}$, temperature, electrical conductivity, turbidity and dissolved oxygen were measured respectively by an ISO-SCAN pH meter, a thermometer incorporated in the $\mathrm{pH}$ meter, a WTW-315i/SET conductivity meter, a $\mathrm{HACH}$ LANGE 2100 ISO turbidimeter and a $\mathrm{HACH}$ LANGE HQ 30d probe oximeter. Sulphate ions were analyzed in the laboratory of the Faculty of Exact and Applied Sciences of the University of Ndjamena using the spectrophotometer HACH DR 2400.

Measurements of metals, in particular, barium $(\mathrm{Ba})$, calcium $(\mathrm{Ca})$, iron $(\mathrm{Fe})$, magnesium $(\mathrm{Mg})$, manganese $(\mathrm{Mn})$, strontium $(\mathrm{Sr})$, aluminium $(\mathrm{Al})$, chromium $(\mathrm{Cr})$, copper $(\mathrm{Cu})$, lead $(\mathrm{Pb})$, Titanium $(\mathrm{Ti})$, Zirconium $(\mathrm{Zr})$ and Tin $(\mathrm{Sn})$ were realized by ICP-OES vista (Agilent) simultaneous system at the laboratory of Applied Sciences of the Claude Bernard University Lyon 1.

In a practical way, the solutions were decanted and then acidified before being submitted to analysis. In parallel, the non-settled solutions were strongly acidified and homogenized in order to have a total concentration. Some solutions 
contained a high proportion of a brown residue, others not at all. Thus, the settled or filtered water contains less toxic metals. The total water (including the residue dissolved by acidification) sometimes contains high levels of metals.

\subsubsection{Data Processing}

Statgraphics plus 5.0 software was used for the analysis of variance (ANOVA) and DUNCAN's multiple comparison test to differentiate the means. Statistical significance was defined for $\mathrm{p}<0.05$.

\section{Results and Discussion}

\subsection{Physicochemical Parameters}

Table 1. Average values of water quality indicator parameters.

\begin{tabular}{lllll}
\hline Parameters & Well water & $\begin{array}{l}\text { Borehole } \\
\text { water }\end{array}$ & River water & $\begin{array}{l}\text { WHO } \\
\text { Standards }\end{array}$ \\
\hline $\mathrm{T}\left({ }^{\circ} \mathrm{C}\right)$ & $27,63 \pm 0,15^{\mathrm{a}}$ & $30,00 \pm 1,01^{\mathrm{b}}$ & $27,66 \pm 0,25^{\mathrm{a}}$ & 25 \\
$\mathrm{pH}$ & $5,34 \pm 0,24^{\mathrm{a}}$ & $5,48 \pm 0,15^{\mathrm{a}}$ & $6,21 \pm 0,27^{\mathrm{b}}$ & $6,5-8,5$ \\
$\mathrm{Cond} .(\mu \mathrm{S} / \mathrm{cm})$ & $27,46 \pm 2,27^{\mathrm{a}}$ & $94,86 \pm 2,25^{\mathrm{b}}$ & $43,3 \pm 0,55^{\mathrm{c}}$ & 400 \\
Turb. $(\mathrm{NTU})$ & $43,40 \pm 1,21^{\mathrm{a}}$ & $2,36 \pm 0,15^{\mathrm{b}}$ & $47,56 \pm 1,5^{\mathrm{c}}$ & 5 \\
$\mathrm{O}_{2}(\mathrm{mg} / \mathrm{l})$ & $2,40 \pm 0,10^{\mathrm{a}}$ & $\mathrm{ND}$ & $4,911 \pm 0,14^{\mathrm{b}}$ & - \\
$\mathrm{SO}_{4}{ }^{2-}(\mathrm{mg} / \mathrm{l})$ & $2,1 \pm 0,10^{\mathrm{a}}$ & $1,28 \pm 0,03^{\mathrm{b}}$ & $1,33 \pm 0,07^{\mathrm{c}}$ & 500 \\
\hline
\end{tabular}

ND: Not determined

\subsubsection{Temperature}

Recorded temperatures vary on average from $27.63 \pm 0.15^{\circ} \mathrm{C}$ for well water, $30.00 \pm 1.01^{\circ} \mathrm{C}$ for borehole water to $27.66 \pm 0.25^{\circ} \mathrm{C}$ for river water (Table 1 ). Well and river water temperatures are approximately equal but differ significantly from borehole water temperatures at the $0.05 \%$ threshold. This difference would be due to different sampling times. High temperatures facilitate the oxidation reactions of nitrogen derivatives $\left(\mathrm{NH}_{4}^{+}, \mathrm{NO}_{2}^{-}\right)$and, consequently, lead to a decrease in the dissolved oxygen rate [16]. These results are similar to those reported by Maoudombaye et al. [17], which were $28.43 \pm 0.11^{\circ} \mathrm{C}$ for well water, $30.65 \pm 0.14^{\circ} \mathrm{C}$ for borehole water and $30.75 \pm 0.12^{\circ} \mathrm{C}$ for river water, respectively.

\subsection{2. $\mathrm{pH}$}

The results obtained show that the waters in the Department of Nyan are acidic (Table 1). There is no significant difference between the $\mathrm{pH}$ value of well water and borehole water at the $0.05 \%$ threshold. These $\mathrm{pH}$ values could be explained by geochemical conditions [18]. Other factors affecting $\mathrm{pH}$ are temperature and organic matter. Increasing temperature decreases the solubility of $\mathrm{CO}_{2}$ and lowers the $\mathrm{pH}$ value. Aerobic decomposition of organic matter releases $\mathrm{CO}_{2}$ and thus causes a decrease in $\mathrm{pH}$. Acidic water can mobilize certain metals from the soil and piping systems, increasing their bioavailability and changing their toxicity $[19,20]$. A low $\mathrm{pH}$ range is detrimental to the environment. It can have an adverse effect on fauna and flora whose growth $\mathrm{pH}$ is between 6.5 and 8.5. It could be one of the causes of tree dieback in this oil zone. The $\mathrm{pH}$ values measured are below the limit value (8.5) set by the WHO. The results are similar to those obtained by Maoudombaye et al, [17] which were $5.47 \pm 0.18$ for well water, $5.76 \pm 0.24$ for borehole water and $6.8 \pm 0.32$ for river water. However, these values are lower than those reported by Ngaram [21], in the waters of the Chari River which ranged between 7.03 and 8.14 .

\subsubsection{Electrical Conductivity}

The mean values of the measured conductivities are respectively $27.46 \pm 2.27 \mu \mathrm{S} / \mathrm{cm}$ for well water, $94.86 \pm 2.25$ $\mu \mathrm{S} / \mathrm{cm}$ for borehole water and $43.3 \pm 0.55 \mu \mathrm{S} / \mathrm{cm}$ for river water (Table 1). These levels are all significantly different from each other. These differences would be due to the geochemical conditions of the watershed. Like $\mathrm{pH}$, electrical conductivity varies according to calcocarbonic equilibrium, so that it also depends on temperature and biological processes. The difference would result from low ionic solubility in rivers. These values are very low compared to the limit value $(400 \mu \mathrm{S} / \mathrm{cm})$ recommended by the WHO for drinking water. According to the classification of Mohammed and Boubekeur [22], the waters in the study area require very low mineralization. Conductivity values for well and river water are similar to those reported by Ngaram [21], in the waters of the Chari River in Chad, which ranged from 13.90 to $52.65 \mu \mathrm{S} / \mathrm{cm}$.

\subsubsection{Turbidity}

The results of the analyses gave the following mean turbidity values: $43.40 \pm 1.21 \mathrm{NTU}$ for well water, $2.36 \pm 0.15$ NTU for borehole water and $47.56 \pm 1.5$ NTU for river water (Table 1). There are significant differences between the values of the different water sources. Water from wells and rivers is very turbid. Their values are well above the WHO guideline value for drinking water quality of 5 NTU. Turbidity is a seasonal phenomenon, which corresponds to the sampling period at the beginning of the rainy season with its corollary the phenomenon of rainwater runoff, putting in suspension sediments which were previously deposited. Turbidity can be detrimental to health as it reduces the effectiveness of disinfection [23]. The average turbidity value for borehole water alone is the WHO guideline value. Turbidity values for well and river water are within the range of values reported by Ngaram [21], which was, based on sampling points, from 17.10 NTU to $117.01 \mathrm{NTU}$.

\subsubsection{Dissolved Oxygen}

The average dissolved oxygen values obtained are as follows: $2.40 \pm 0.10 \mathrm{mg} / \mathrm{L}$ for well water and $4.911 \pm 0.14 \mathrm{mg} / \mathrm{L}$ in river water (Table 1). There is a significant difference between these values at the threshold of $0.05 \%$. The maximum acceptable dissolved oxygen concentration recommended for the protection of aquatic life is between 6.5 and $9.5 \mathrm{mg} / \mathrm{L}$ [24]. Aerated oxygen-saturated water at $25^{\circ} \mathrm{C}$ should have an oxygen concentration in equilibrium with atmospheric pressure greater than $7 \mathrm{mg} / \mathrm{L}$. The average content in unpolluted surface water is $8 \mathrm{mg} / \mathrm{L}$ and barely exceeds $10 \mathrm{mg} / \mathrm{L}$ [25]. Dissolved oxygen is an important parameter to take into consideration, as it provides information on the state of the well and, on the other hand, it 
promotes the growth of microorganisms that degrade organic matter. In general, low values of dissolved oxygen favour the development of pathogenic germs [26]. When the dissolved oxygen content is less than $3 \mathrm{mg} / \mathrm{l}$, the water is considered of poor quality (significant pollution). Dissolved oxygen plays a primary role in the maintenance of aquatic life and in selfpurification. Its presence in natural waters is mainly determined by the respiration of organisms, by the photosynthetic activity of the flora, by the oxidation and degradation of pollutants and finally by air-water exchanges [27]. If oxygen levels were to remain close to 2.5 to $3 \mathrm{mg} / \mathrm{L}$, fish would usually die [28].

\subsubsection{Sulphates}

The average values of sulphate ions measured are as follows: $2.1 \pm 0.10 \mathrm{mg} / \mathrm{L}$ in well water, $1.28 \pm 0.03 \mathrm{mg} / \mathrm{L}$ in borehole water and $1.33 \pm 0.07 \mathrm{mg} / \mathrm{L}$ in river water (Table 1). These mean values are all significantly different from each other at the $0.05 \%$ threshold. Sulphates come from runoff or infiltration in gypsum soils. They also result from the activity of certain bacteria (chlorothiobacteria, rhodothiobacteria, etc.). This activity can oxidize toxic hydrogen sulfide $\left(\mathrm{H}_{2} \mathrm{~S}\right)$ into sulfate [29]. Surface waters contain highly variable levels of sulphate. Their concentration is generally between 2.2 and $58 \mathrm{mg} / \mathrm{L} \mathrm{[30].}$

\subsection{Heavy Metals}

Table 2. Average values of heavy metals by water source.

\begin{tabular}{lllll}
\hline Parameters & Well water & $\begin{array}{l}\text { Borehole } \\
\text { water }\end{array}$ & River water & $\begin{array}{l}\text { WHO } \\
\text { standards }\end{array}$ \\
\hline $\mathrm{Ca}(\mathrm{mg} / \mathrm{L})$ & $1,848 \pm 0,012^{\mathrm{a}}$ & $1,330 \pm 0,007^{\mathrm{b}}$ & $0,890 \pm 0,004^{\mathrm{c}}$ & 100 \\
$\mathrm{Mg}(\mathrm{mg} / \mathrm{L})$ & $0,264 \pm 0,002^{\mathrm{a}}$ & $0,286 \pm 0,001^{\mathrm{a}}$ & $0,326 \pm 0,002^{\mathrm{b}}$ & 50 \\
$\mathrm{Cr}(\mathrm{mg} / \mathrm{L})$ & $0,000 \pm 0,000^{\mathrm{a}}$ & $0,001 \pm 0,000^{\mathrm{b}}$ & $0,000 \pm 0,000^{\mathrm{a}}$ & 0,05 \\
$\mathrm{Cu}(\mathrm{mg} / \mathrm{L})$ & $0,001 \pm 0,000^{\mathrm{a}}$ & $0,053 \pm 0,001^{\mathrm{b}}$ & $0,002 \pm 0,000^{\mathrm{c}}$ & 2 \\
$\mathrm{Ba}(\mathrm{mg} / \mathrm{L})$ & $0,005 \pm 0,000^{\mathrm{a}}$ & $0,053 \pm 0,001^{\mathrm{b}}$ & $0,022 \pm 0,000^{\mathrm{c}}$ & 1 \\
$\mathrm{Mn}(\mathrm{mg} / \mathrm{L})$ & $0,017 \pm 0,000^{\mathrm{a}}$ & $0,093 \pm 0,001^{\mathrm{b}}$ & $0,002 \pm 0,000^{\mathrm{c}}$ & 0,05 \\
$\mathrm{Al}(\mathrm{mg} / \mathrm{L})$ & $5,614 \pm 0,009^{\mathrm{a}}$ & $0,05 \pm 0,001^{\mathrm{b}}$ & $1,211 \pm 0,008^{\mathrm{c}}$ & 0,2 \\
$\mathrm{Fe}(\mathrm{mg} / \mathrm{L})$ & $0,072 \pm 0,001^{\mathrm{a}}$ & $7,890 \pm 0,016^{\mathrm{b}}$ & $0,866 \pm 0,003^{\mathrm{c}}$ & 0,3 \\
$\mathrm{~Pb}(\mathrm{mg} / \mathrm{L})$ & $0,00 \pm 0,000^{\mathrm{a}}$ & $0,033 \pm 0,001^{\mathrm{b}}$ & $0,001 \pm 0,000^{\mathrm{c}}$ & 0,05 \\
$\mathrm{Ti}(\mathrm{mg} / \mathrm{L})$ & $1,240 \pm 0,008^{\mathrm{a}}$ & $0,075 \pm 0,000^{\mathrm{b}}$ & $0,611 \pm 0,007^{\mathrm{c}}$ & - \\
$\mathrm{Zr}(\mathrm{mg} / \mathrm{L})$ & $0,029 \pm 0,000^{\mathrm{a}}$ & $0,015 \pm 0,000^{\mathrm{b}}$ & $0,110 \pm 0,002^{\mathrm{c}}$ & - \\
$\mathrm{Sr}(\mathrm{mg} / \mathrm{L})$ & $0,005 \pm 0,000^{\mathrm{a}}$ & $0,006 \pm 0,000^{\mathrm{b}}$ & $0,007 \pm 0,000^{\mathrm{c}}$ & - \\
$\mathrm{Sn}(\mathrm{mg} / \mathrm{L})$ & $<\mathrm{LDD}$ & $0,306 \pm 0,001^{\mathrm{a}}$ & $0,017 \pm 0,000^{\mathrm{b}}$ & - \\
\hline
\end{tabular}

LDD: Limit of Quantitation

\subsubsection{Calcium}

The analysis in Table 2 shows that calcium levels in the different water sources range from $1.848 \pm 0.012 \mathrm{mg} / \mathrm{L}(1.712$ to 1.966$)$ for well water, $1.330 \pm 0.007 \mathrm{mg} / \mathrm{L}(1.01$ to 1.61 $\mathrm{mg} / \mathrm{L})$ for borehole water to $0.890 \pm 0.004 \mathrm{mg} / \mathrm{L}(0.854$ to $0.943 \mathrm{mg} / \mathrm{L}$ ) for river water. This level is significantly lower $(p<0.05)$ in river water than in borehole and well water. This difference would be related to the nature of the land crossed. Calcium is generally the dominant element in drinking water and its content varies essentially according to the nature of the land crossed (limestone or gypsum) [31]. Adverse effects that are mainly organoleptic or aesthetic in nature resulting from the presence of calcium in drinking water may stem from its contribution to hardness [32]. The WHO recommends a guideline value of $100 \mathrm{mg} / \mathrm{L}$ for the calcium content in water intended for human consumption. However, the values obtained are very low at the WHO level [33]. These values confirm the low electrical conductivity values obtained from the same sources (Table 1). These waters have mineralization ranging from very low to low. The results obtained in the analyses are very low compared to those of Ble et al. [34] who reported averages of 24 to $49 \mathrm{mg} / \mathrm{L}$ in "la Rosée" water, 55 to $56.7 \mathrm{mg} / \mathrm{L}$ in "Amina" water and 1.2 to 2 $\mathrm{mg} / \mathrm{L}$ in "la source" water in Senegal.

\subsubsection{Magnesium}

Magnesium values measured in the different sources vary from 0.253 to $0.29 \mathrm{mg} / \mathrm{L}$ with an average of $0.264 \pm 0.002$ $\mathrm{mg} / \mathrm{L}$ for well water, from 0.235 to $0.265 \mathrm{mg} / \mathrm{L}$ with an average of $0.286 \pm 0.001 \mathrm{mg} / \mathrm{L}$ for borehole water, and from 0.245 to $0.491 \mathrm{mg} / \mathrm{L}$ with an average of $0.326 \pm 0.002 \mathrm{mg} / \mathrm{L}$ for river water (Table 2). There is no significant difference at the $0.05 \%$ threshold between the magnesium value of well water and borehole water. On the other hand, these two values differ significantly from those of river water. This slightly higher value in river water is related to the dissolution of magnesium in the air. Magnesium is an indispensable element in the metabolism of the human body, and it is crucial for more than 300 enzymatic reactions [35], including all those using adenosine triphosphate [36]. The WHO recommends a value of $50 \mathrm{mg} / \mathrm{L}$ of magnesium for drinking water. The values obtained from the various sources are very negligible compared to the WHO guideline value. Timoléon et al [37] obtained values of $2.3 \mathrm{mg} / \mathrm{L}, 71.25 \mathrm{mg} / \mathrm{L}$ and $39.16 \mathrm{mg} / \mathrm{L}$ respectively from water wells P1, P2 and P3 in Brazzaville City, Congo.

\subsubsection{Chromium}

The average chromium values obtained are $0.00 \pm 0.000$ $\mathrm{mg} / \mathrm{L}$ in well water, $0.001 \pm 0.000 \mathrm{mg} / \mathrm{L}(0.00$ to $0.002 \mathrm{mg} / \mathrm{L})$ in borehole water, and $0.000 \pm 0.000 \mathrm{mg} / \mathrm{L}$ in river water (Table 2). Chromium levels in well and river water are zero, and differ significantly from those in borehole water. At low doses, chromium (III) is an essential nutrient for humans since it plays an indispensable role in carbohydrate metabolism as an insulin activator [38, 39]. Its deficiency can cause heart problems, metabolic disturbances and diabetes (interruption of sugar metabolism). But excessive chromium (III) absorption can also cause health problems, such as skin rashes [40]. The WHO, as well as the directives of the Council of the European Communities and the French regulation on the quality of water intended for human consumption have adopted the figure of $0.05 \mathrm{mg} / \mathrm{L}$ as the limit value for chromium [41]. The values obtained are all within the WHO concentration range for drinking water. The values obtained are low compared to those reported by Ngaram [21] in Chari waters which ranged from 0.02 to 0.11 $\mathrm{mg} / \mathrm{L}$. According to Rodier et al. [32], fresh surface water contains only small amounts of chromium of 5 to $10 \mu \mathrm{g} / \mathrm{L}$.

\subsubsection{Copper}

Copper levels in Table 2 range from 0.001 to $0.0012 \mathrm{mg} / \mathrm{L}$ 
with an average of $0.001 \pm 0.000 \mathrm{mg} / \mathrm{L}$ for well water, 0.04 to $0.07 \mathrm{mg} / \mathrm{L}$ with an average of $0.053 \pm 0.001 \mathrm{mg} / \mathrm{L}$ for borehole water, to 0.001 to $0.003 \mathrm{mg} / \mathrm{L}$ with an average of $0.002 \pm 0.000$ $\mathrm{mg} / \mathrm{L}$ for river water. Statistical analyses show that the copper levels in the different water sources differ significantly from one another. These differences would be due to the geological context. Copper is an essential element in humans and animals (trace element), involved in many metabolic pathways, including hemoglobin formation and neutrophil maturation. In addition, it is a specific co-factor of many enzymes and structural metallo-proteins [38]. However, excess copper produces free radicals responsible for cellular damage to DNA and organelles such as mitochondria or lysosomes [42]. For water intended for human consumption, the WHO recommends a provisional guide value of $2 \mathrm{mg} / \mathrm{L}$, given the uncertainties of copper toxicity to humans. All values obtained are below the WHO guideline value. The values obtained in the analyses are lower than those reported by Ngaram [21] which were 0.07 to $0.17 \mathrm{mg} / \mathrm{L}$. N'Diaye et al [43] reported a mean value of $300 \pm 290 \mu \mathrm{m} / \mathrm{L}(0$ to $740 \mu \mathrm{m} / \mathrm{L})$ in water from the right bank of the Senegal River.

\subsubsection{Barium}

Average Barium levels in different water sources range from $0.005 \pm 0.000 \mathrm{mg} / \mathrm{L}(0.004$ to $0.008 \mathrm{mg} / \mathrm{L})$ in well water, $0.053 \pm 0.001 \mathrm{mg} / \mathrm{L}(0.04$ to $0.07 \mathrm{mg} / \mathrm{L})$ in borehole water to $0.022 \pm 0.000 \mathrm{mg} / \mathrm{L}(0.020$ to $0.023 \mathrm{mg} / \mathrm{L})$ in river water (Table 2). This barium content is significantly higher $(\mathrm{p}<$ 0.05 ) in borehole and river water than in well water. This significant difference in barium levels between water sources is related to the geological context [44]. Barium is not metabolized in the body but can be transported or incorporated metabolically into certain tissues (especially bone) [45]. Excretion of barium is primarily via the fecal route and to a lesser extent via the urinary route [44]. Drinking water quality guidelines set the maximum acceptable concentration of barium in drinking water at 1 $\mathrm{mg} / \mathrm{L}$ [46]. All values obtained are below this maximum acceptable concentration. Analyses of barium concentration in feed water are infrequent, so that to date, analysis of this parameter has not been done systematically. The regulatory requirement is 1 sample every 2 years to 1 every 5 years for small communities. Thus, it is difficult to have scientific data on barium in groundwater over time [44].

\subsubsection{Manganese}

Manganese results in Table 2 range from 0.011 to 0.029 $\mathrm{mg} / \mathrm{L}$ with an average of $0.017 \pm 0.000 \mathrm{mg} / \mathrm{L}$ in well water, 0.081 to $0.11 \mathrm{mg} / \mathrm{L}$ with an average of $0.093 \pm 0.001 \mathrm{mg} / \mathrm{L}$ in borehole water, and 0.001 to $0.003 \mathrm{mg} / \mathrm{L}$ with an average of $0.002 \pm 0.000 \mathrm{mg} / \mathrm{L}$ in river water. This level is significantly higher $(\mathrm{p}<0.05)$ in borehole water than in river and well water. Manganese is an essential element for animals and humans. Concentrations that may threaten health are much higher than those that affect the organoleptic qualities of water. The WHO recommends a value of $0.05 \mathrm{mg} / \mathrm{L}$ manganese for drinking water. Manganese values for well and river water meet the WHO standard for this parameter.
On the other hand, the manganese content of borehole water $(0.093 \pm 0.01 \mathrm{mg} / \mathrm{L})$ is higher than this standard. The results obtained in the analyses are all lower than those reported by Ngaram [21] in the Chari waters, which were 0.26 to 0.5 $\mathrm{mg} / \mathrm{L}$. On the other hand, N'Diaye et al [43] reported a very low mean value of $2.88 \pm 2.42 \mu \mathrm{m} / \mathrm{L}$ in water from the right bank of the Senegal River.

\subsubsection{Aluminium}

The average aluminum values in the different water sources range from $5.412 \pm 0.008 \mathrm{mg} / \mathrm{L}(5.571$ to $5.412 \mathrm{mg} / \mathrm{L})$ in well water, $0.05 \pm 0.001 \mathrm{mg} / \mathrm{L}(0.4$ to $0.06 \mathrm{mg} / \mathrm{L})$ in borehole water, to $1.211 \pm 0.008 \mathrm{mg} / \mathrm{L}(1.119$ to $1.295 \mathrm{mg} / \mathrm{L})$ in river water (Table 2). All these values differ significantly from each other at the $0.05 \%$ threshold. The very high aluminum content in river water and well water would be related respectively to the dissolution of aluminum present in the air under dust particles or acid rain, and to the mobilization of aluminum from acid soil. Aluminum is also present in the form of dust particles in the air, with aluminum silicates contributing significantly to the levels of these dusts from the soil [47]. Most water authorities around the world also use aluminum sulfate (alum) as a coagulant in water treatment plants. Based on current knowledge on the toxicity of aluminum, the $\mathrm{WHO}$ has adopted a guideline value for aluminum in drinking water of $0.2 \mathrm{mg} / \mathrm{l}$, a value not based on health considerations, but on considerations of coloration of the treated water. This guideline value is established primarily for taste and appearance reasons [48]. Only the aluminium content in borehole water meets the WHO standard. The aluminum content in well and river water is well above the WHO guideline value.

\subsubsection{Iron}

Mean iron values in Table 2 range from $0.072 \pm 0.001 \mathrm{mg} / \mathrm{L}$ $(0.054$ to $0.091 \mathrm{mg} / \mathrm{L})$ in well water, $7.890 \pm 0.016 \mathrm{mg} / \mathrm{L}$ (7.711 to $8.045 \mathrm{mg} / \mathrm{L})$ in borehole water to $0.866 \pm 0.003$ $\mathrm{mg} / \mathrm{L}(0.845$ to $0.904 \mathrm{mg} / \mathrm{L})$ in river water. All these values are all significantly different from each other. The differences would be explained by the atmospheric deposition at the level of rivers, by the oxidation of iron materials used in the pumping system at the level of borehole water. Iron is a micronutrient essential for life. It is used in the constitution of haemoglobin. It is involved in many enzymatic functions. Iron deficiency or excess are both harmful [49]. The maximum acceptable concentration in drinking water has been set at $0.3 \mathrm{mg} / \mathrm{L}$ to preserve its aesthetic qualities [50]. Only well water meets the WHO standard for drinking water. Iron values in river and borehole water are slightly and significantly higher than the WHO standard, respectively. The results obtained in river waters are similar to those reported by Ngaram [21] in Chari waters ranging from 0.90 to $1.90 \mathrm{mg} / \mathrm{L}$. In contrast, N'Diaye et al [43] reported mean values of $246.25 \pm 56.05 \mu \mathrm{m} / \mathrm{L}$ in the waters of the right bank of the Senegal River.

\subsubsection{Lead}

Lead concentrations in well water are $0.00 \pm 0.000 \mathrm{mg} / \mathrm{L}$, 
compared to $0.033 \pm 0.001 \mathrm{mg} / \mathrm{L}(0.02$ to $0.04 \mathrm{mg} / \mathrm{L})$ in borehole water and $0.001 \pm 0.000 \mathrm{mg} / \mathrm{L}(0.001$ to $0.002 \mathrm{mg} / \mathrm{L})$ in river water (Table 2). Lead values obtained in different water sources differ significantly from each other at the $0.05 \%$ threshold. The high value of lead in borehole water would be due to the metallurgical wastes left in the ground during the oil installations. Lead is not a trace element and has a well-known toxic character. Both organic and inorganic forms of $\mathrm{Pb}$ have toxic effects in humans. However, the toxicity of organic species is much greater than that of inorganic species, as its passage through the food chain is privileged in humans [51]. The WHO indicates for water intended for human consumption a maximum allowable concentration of 0.05 $\mathrm{mg} / \mathrm{L}$ of lead. Lead values in the different water sources meet this WHO guideline value. These values are close to those reported by Ngaram [21] were 0.01 to $0.04 \mathrm{mg} / \mathrm{L}$. They are also close to those reported by N'Diaye et al [43] which were $2.76 \pm 4.23 \mu \mathrm{m} / \mathrm{L}$ (0 to $9.20 \mu \mathrm{m} / \mathrm{L}$ ) in water from the right bank of the Senegal River.

In addition, metals such as zirconium, strontium, titanium and tin do not have numerical guidelines required for drinking water quality (Table 2). Zirconium and its salts are generally considered to have low systemic toxicity. Zirconium is not classified as a carcinogen or potential carcinogen, but appears to have the potential to cause allergies [52]. Strontium is not an undesirable or toxic element according to current regulations. However, some groundwater is highly concentrated in this element, up to 52 $\mathrm{mg} / \mathrm{L}$, which is one of the highest concentrations reported for drinking water [53]. The distribution of strontium in minerals, rocks, sediments, and water is often related to that of calcium [54]. For titanium, titanium dioxide $\left(\mathrm{TiO}_{2}\right)$ is used as a biocompatible white pigment [55]. $\mathrm{TiO}_{2}$ is a metal oxide that is widely used as a white food colorant (additive E171) in confectionery, sauces, baking, but its bactericidal properties also promise widespread use in the packaging sector for the design of bio-based thin films with antimicrobial properties [56]. Tin has low toxicity in humans. It is rarely found naturally in soil and water. Most of the time, tin present in groundwater comes from industrial effluents. Chronic inhalation of oxides (dusts, vapours) can cause stannosis (benign pneumoconiosis) without changes in respiratory function [57].

\section{Conclusion}

The study of heavy metals in the various water resources intended for human consumption has shown that these water sources can be considered as potential sources of health risks in view of the results of the parameters analyzed. The waters in the Department of Nyan have an acid $\mathrm{pH}$. The $\mathrm{pH}$ of a soil is of great importance for fertility, particularly for its ability to make nutrients available to plants. A high introduction of acids into the soil leads to a decrease in plant growth. In acidic soil, the nutrient ions $\left(\mathrm{Mg}^{2+}\right.$ and $\left.\mathrm{Ca}^{2+}\right)$ therefore only remain bound to clays or other compounds in very small quantities. They are removed from the clays and transported to the deep layers of the soil by precipitation water. The same applies to silicates and carbonates, which are thus removed from the roots of plants. Metals such as manganese, iron and aluminum exceed international standards for drinking water quality in some sources, which would not be without consequences for human health. These metals could lead to, among other things, cardiovascular disease, immunological pathologies, disruption of the reproductive and endocrine systems, and have cytotoxic effects.

\section{References}

[1] Adriano D. C. (2001) Trace elements in terrestrial environments: Biochemistry, bioavailability and risks of metals. Springer-Verlag, New York.

[2] Baize D., Sterckeman T. (2001) of the necessity of knowledge of the natural pedo-geochemical background content in the evaluation of the contamination of soils by trace elements. Science of the Total Environment, 264: 127-139.

[3] Miquel G. (2001) The effects of heavy metals on the environment and health. Parliament office of evaluation of scientific and technological choices. Report. $365 \mathrm{p}$.

[4] Matias M. S. A. (2008) Heavy Metal Contamination of Surface Water and Sediments in the Val de Milluni (Bolivian Andes) by Mining Waste Geochemical, Mineralogical and Hydrochemical Approaches. Ph. D. Thesis Ph. D. Sciences of the Universe. Université Paul Sabatier - Toulouse III, 491 p.

[5] Aoun M. (2009) Action of cadmium on Indian mustard plants [Brassica juncea (L.) Czern] born from thin cell layers from seedlings. Physiological analyses and role of polyamines. $\mathrm{PhD}$ thesis from the University of Western Brittany. 137.

[6] Jie W., Liang S., Lulu Z., Haowen Z., Shengxiao W., Jianwen Z., Zhenguo S., Chunlan L., Yahua C. (2020). Analysis of the long-term effectiveness of biochar immobilization remediation on heavy metal contaminated soil and the potential environmental factors weakening the remediation effect: A review. Ecotoxicology and Environmental Safety 207 (2021) 111261.

[7] Kyung-Min Lim (2010) Faculty of Pharmacy, Seoul National University, Korea: Low-Level Mercury Can Enhance Procoagulant Activity of Erythrocytes: A New Contributing Factor for Mercury-Related Thrombotic Disease, Environmental Health Perspectives, July 2010.

[8] Council of Europe (2011) Health Risks of Heavy Metals. Report of the Social, Health and Family Affairs Committee. $13 \mathrm{p}$.

[9] CIRAD (2005) Plan of regional development in the oil area (Chad), final report, Ndjamena, CTNSC, $117 \mathrm{p}$.

[10] Maoudombaye T., Ndoutamia G., Ngakou A. (2016) Evaluation of the bacteriological quality of well, borehole and river water consumed in the Doba oil basin in Chad. International Journal of Recent Scientific Research, 7 (6): 12236-12243.

[11] Djéralar M. (2010) Living with oil. Study on the living conditions of villages in the Doba oil zone in Chad. Report. 90 p. 
[12] WHO (1971) European standards for drinking water, 2nd edition, Geneva, $62 \mathrm{p}$.

[13] Ngaram N., Yohann C, Alain M, Tchadanaye N. M., Pierre L. (2017) Heavy metal pollution of Chari river water during the crossing of N'Djamena (Chad). Toxics 2017, 5, 26; doi: $10.3390 /$ toxics 5040026 .

[14] Lallemand-Barres A. (1993) Practical guide for the sampling of sub-ground water. BRGM Report R $37390.95 \mathrm{p}$.

[15] Vaute L. (1998) Groundwater monitoring in the Lorraine femfere basin in 1998. BRGM Report R 40789. $69 \mathrm{p}$.

[16] Nathalie M. (1999) Physico-chemical and biological characterization of Nouvelle-Calédonie water-stream. Proposal of a biotic index on the study of the benthic macro invertebrates. Doctoral thesis, French University of the Pacific, 200 p.

[17] Maoudombaye T., Ndoutamia G., Seid Ali M., Ngakou A. (2015) Comparative study of the physico-chemical quality of well, borehole and river water consumed in the Doba oil basin in Chad. Larhyss Journal, 24: 193-208.

[18] Boubakar H. A. (2010) Superficial and profound aquifers and urban pollution in Africa: The Case of urban community of Niamey (Niger), Thesis from Abdou Moumouni of Niamey (Niamey), $198 \mathrm{p}$

[19] Traina S. J., Laperche V. (1999) Contaminant bioavailability in soils, sediments, and aquatic environments. Proc. Natl. Acad. Sci. U.S.A., 96 (7): 3365-3371.

[20] Langmuir D., Chrostowski P., Vigneault B., Chaney R. (2005) Issue paper on the environmental chemistry of metals. U.S. Environmental Protection Agency Risk Assessment Forum. Washington, DC 20460 Contract \#68-C-02-060.

[21] Ngaram N. (2011) Contribution to the analytical study of heavy metal type pollutants in the waters of the Chari River during its crossing of the city of N'djamena. Ph. D. thesis $\mathrm{Ph}$. D. Université Claude Bernard Lyon1, $164 \mathrm{p}$.

[22] Mohammed El k., Boubekeur H. (2008) Study of physicochemical and bacteriologiccal of consumption water of Ain Yousef from the dam of Sekkak, pp. 32-36.

[23] Canadian Council of Ministers of the Environment (CCME) (2008) Canadian Water Quality Guidelines. 1717p.

[24] Derwich E., Benaabidate L., Zian A., Sadki O., Belghity D. (2010) Physico-chemical Characterization of alluvial sheet water of Haut Sebou downstream its confluence with Oued Fes. Larhyss Journal, 8: 101-112.

[25] Canadian Council of Ministers of the Environment (CCME). (1999) Canadian Environmental Quality Guidelines. Winnipeg: The Council.

[26] Hazourli S., Boudiba L., Ziati M. (2007) Caractérisation de la pollution des eaux résiduaires de la zone industrielle d'ElHadjar, Annaba. Larhyss Journal, 1112-3680, n6: 45-55.

[27] Belghiti L., Chahlaoui A., El Moustaine R., Bengoumi D. (2013) Contribution to the Study of the bacteriologic quality of water sources in Elhajeb city (Meknès Marroco). Larhyss Journal, 14: 37-47.

[28] HCEFLCD (Haut-Commissariat Aux Eaux et Forêt et la Lutte Contre la Désertification) (2007) Diagnostic study of the AL Massira-Faija wetland, cercle of EL Brouj and Cercle of Settat
(Morocco), $242 \mathrm{p}$.

[29] Meinck F., Stooff H., Kohlschütter H. (1977) Industrial residual water, 2nd Ed. Masson, Paris, 863p.

[30] HCEFLCD (Haut-Commissariat Aux Eaux et Forêt et la Lutte Contre la Désertification), 2006. Study on pisciculture in the dam of Almassira, CR dar CHAFAAI, Cercle of EL BROUGE, Province of Settat, 201p.

[31] Meybeck M., Friedrich G., Thomas R., Chapman D. (1996) Rivers. Water quality assessments: a guide to the use of biota, sediments and water in environment monitoring, Chapman edition, 2nd ed. E \& FN Spon, London, pp. 59-126.

[32] Rodier J., Legube B., Merlet N. (2009) Water's analysis. 9th edition. Dunod. Paris, 1526 p.

[33] AWWA (American Water Works Association) (1990) Water quality and handbook of community water supplies, 4th edition. F. W. Pontius (ed.), McGraw-Hill, New York, NY.

[34] Ble L. O., Soro T. D., Dje K. B., Degny G. S., Biemi J. (2015) Waters packaged in sachets: what are the risks of exposure for the populations of the district of Abidjan? Larhyss Journal, 24: 85-107.

[35] Ebel H., Gunther T. (1980) Magnesium metabolism: a review. J. Clin. Chem. Clin. Biochem, 18: 257.

[36] Dams R., Robbins J. A., Rahn K. A., Winchester J. W., 1971. Quantitative relationships among trace elements over industrialized northwest Indiana. In: Nuclear techniques in environmental pollution. International Atomic Energy Agency, Vienna. p. 139.

[37] Timoléon A. B. and Bouaka F. (2013) Physicochemical characterization and chlorination of well water consumed in the city of Brazzaville-Congo. J. Mater. Approximately. Sci. 4 (5): 605-612.

[38] Piotr G., Grzegorz C., Aleksandra Z., Karolina W., Joanna S. (2020) Long-term effect of heavy metals $\mathrm{Cr}(\mathrm{III}), \mathrm{Zn}(\mathrm{II})$, $\mathrm{Cd}(\mathrm{II}), \mathrm{Cu}(\mathrm{II}), \mathrm{Ni}(\mathrm{II}), \mathrm{Pb}(\mathrm{II})$ on the anammox process performance. Piotr Gutwiński, Journal of Water Process Engineering, https://doi.org/10.1016/j.jwpe.2020.101668.

[39] Aurélie D. (2004) Caractérisation des risques induits par les activités agricoles sur les écosystèmes aquatiques. $\mathrm{PhD}$ thesis. Ecole nationale du génie rural, des eaux et des forêts Montpellier, $269 \mathrm{p}$.

[40] Mancuso T. F. (1991) Consideration of chromium as an industrial carcinogenicity. Int. Conf. Heavy metals Environment. Toronto, ON, Canada, 27 (31): 343-356.

[41] Ghachi A. (1982) The basin of Seybouse (Algeria). Hydrology and use of water resources. Doctoral thesis, University of Nancy II, France, 508 p.

[42] Pichard A. (2003) Toxicological and environmental data sheet for chemical substances, copper and its derivatives. $66 \mathrm{p}$.

[43] N'diaye A. D., Khadijettou M., Mohamed O. (2013) Contribution to the study of the physico-chemical quality of water on the right bank of the Senegal River. Larhyss Journal, 12: $71-83$.

[44] Elluin M., Host S., Krakowiak D. (2005) Evaluation and management of barium exposure. Workshop Santé Environnement - IGS - ENSP. 71 p. 
[45] ATSDR (2004) Toxicological profiles for Ammonia. Agency for Toxic Substances and Disease Registry, Atlanta, GA: U. S. Department of Health and Human Services, 269 p.

[46] HWC (Health and Welfare Canada) (1982) Guidelines for Canadian Drinking Water Quality, 1978. Department of National Health and Welfare, Ottawa, Canada, 646 p.

[47] Degbey C. (2011) Factors associated with the problem of drinking water quality and the health of populations in the commune of Abomey-calavi in Benin. Doctoral thesis in Public Health Sciences. Université Libre de Bruxelles (ULB). General, 112 p.

[48] WHO (2011) Guidelines for drinking water quality. 4th edition. Geneva, Switzerland. pp. 307-447.

[49] Anonymous (2007) Britannica Encyclopedia. Sociedad Comercial Editorial santiago Ltda, Lima, 2800 p.

[50] HWC (Health and Welfare Canada) (1989) Guidelines for Canadian Drinking Water Quality, Supporting Documents, Prepared by the Federal-Provincial Subcommittee on Drinking Water, Ottawa, Canada, 114 p.

[51] Nriagu J. O. (1978) The biogeochemistry of lead in the environment. Elsevier, Amsterdam, 1011 pp.
[52] Williams R. M., Skipworth G. B., 1959. "Zirconium granulomas of the glabrous skin following treatment of rhus dermatitis." Archives of Dermatology. 80: 273-276.

[53] Hem J. D. (1971) Study and interpretation of the chemical characteristics of natural water. 2nd ed Geological Survey Warer-Supply Paper 1473, United States Govemment Printing Office, Washington, D.C., 363 p.

[54] AFSSA (Agence Française de Sécurité Sanitaire des Aliments) (2009) Nanotechnologies and nanoparticles in food and feed. RCCP-Ra-NanoFood.

[55] Wehmiller J. (1972) The Encyclopedia of Geochemistry and Environmental Sciences. Encyclopedia of Earth Sciences Series, vol. IVA, edited by R. W. Fairbridge, Van Nostrand Reinhold Company, New York, 1321 p.

[56] Yu B., Leung K. M., Guo Q., Lau W. M., Yang J. (2011) Synthesis of Ag-TiO2 composite nano thin film for antimicrobial application. Nanotechnology 22, 115603.

[57] STEM Group. (2011) Antimony tin alloy. Safety data sheet. Consultants / Xstrata Zinc Canada. 5 p. 